\title{
Geography of British Fisheries: Discussion
}

Author(s): Lord Lucas, Norval W. Helme, E. W. MacBride, H. G. Maurice and F. Grant Ogilvie

Source: The Geographical Journal, Vol. 45, No. 6 (Jun., 1915), pp. 491-497

Published by: geographicalj

Stable URL: http://www.jstor.org/stable/1780139

Accessed: 19-06-2016 23:08 UTC

Your use of the JSTOR archive indicates your acceptance of the Terms \& Conditions of Use, available at

http://about.jstor.org/terms

JSTOR is a not-for-profit service that helps scholars, researchers, and students discover, use, and build upon a wide range of content in a trusted digital archive. We use information technology and tools to increase productivity and facilitate new forms of scholarship. For more information about JSTOR, please contact support@jstor.org.

The Royal Geographical Society (with the Institute of British Geographers), Wiley are collaborating with JSTOR to digitize, preserve and extend access to The Geographical Journal 
annual report of the Lancashire and Western Fisheries District; see also 'The Depths of the Ocean,' by Sir John Murray and Dr. Johan Hjort, 1912, and 'Conditions of Life in the Sea,' by James Johnstone, 1908.

B. Special.-1. Hydrography: D. J. Matthews, 'North Sea Fishery Investigations, Southern Area,' Cd. 5546, 1911 ; D'A. W. Thompson, 'Idem., Northern Area,' Cd. 4893, 1909; other Bluebooks by same authors and publications of Conseil permanent, in particular those by Otto Pettersson, B. Helland Hansen and Martin Knudsen; also Hans Pettersson, 'Long Periodical Variations of Tidegenerating Force,' Pub. de Circonstance, No. 65. 2. Plaice: Friedrich Heincke, 'Rapports,' etc., Oct. 1913, and A. T. Masterman, 'Rapports,' etc., several reports, also Bluebook in press. 3. Cod and Herring: Johan Hjort, 'Rapports,' etc., 1914, and several publications by other authors in same series. 4. Mackerel: E. Ehren. baum, 'Rapports,' etc., 1914 ; E. J. Allen, Journ. Marine Biol. Ass., vol. 8, p. 394, 1910; D. Nilsson, Pub. de Circonstance, No. 69, distributed April, 1915. 5. Eel: Johs. Schmidt, 'Rapports,' etc., 1906 and 1914.

The Presidenw (before the lecture): Prof. Stanley Gardiner, who is going to lecture to us to-night on Sea Fisheries, is an old friend of the Society. He is now Professor of Zoology and Comparative Anatomy at Cambridge. For the last twenty years he has been doing oceanographical work of different kinds in the Pacific Ocean, the Indian Ocean, the Maldive and Laccadive Islands, and elsewhere, and the results of these travels he has brought back to the Society, from which he received the Murchison Award. Prof. Gardiner is now a member of the Government Advisory Committee on Sea Fisheries. This has led him to investigate the very important question of the distribution of fishes, and some of the results of his more recent work he will communicate to us to-night.

Lord Lucas (after the lecture) : I have long known Prof. Gardiner by reputation as having been one of the keenest and most learned of the students of this great science, and as having been one of the men who stands out among the many scientists to whom we at the Board of Agriculture and Fisheries owe a great debt of gratitude for the way in which he has put his great knowledge and his time and services at our disposal. I am very glad to be here to-night to express our thanks to Prof. Gardiner. We have had a great deal of work from him on the Advisory Committee on Fisheries Research, and since the war broke out Prof. Gardiner has been studying on our behalf a number of fisheries questions arising out of it. I am sure every one who has heard his lecture to-night will agree we could not have had better assistance, we could not have chosen a better or more skilful scientist to help us in these matters, and we owe a great deal to him for the work he has done. May I be permitted, also, to express my pleasure to-night that the Royal Geographical Society has interested itself in the question of the fishing industry of this country? The figures with which Prof. Gardiner opened his lecture to-night show what a gigantic industry it is-an industry which employs 125,000 men, in which there is invested a sum which he estimates at $£ 200,000,000$, is indeed a large industry ; but from the very nature of it, except those few people who happen to come into contact with it at the ports where it is carried out, the country as a whole has very little knowledge about it. All they know, as a rule, is that the price of fish varies from day to day. Bad weather produces bad fishing, and seasonal conditions generally affect the supply. Sometimes, for instance, for no reason that we know of positively, we learn that the herring fishing has been a failure, because the herrings have chosen not to follow their usual route. We know nothing, or next to nothing, about the conditions of hardship under which this industry is followed. The photograph we saw to-night of those men fishing in the Barents Sea is probably 
something perfectly novel to most people. The fact that all the year round we have trawlers going to that most dangerous and most difficult of seas and catching fish under conditions of the greatest hardship is unknown to the majority of people in this country, and I should like to express our gratitude to you for the line you have taken in allowing a good deal of to-night to be devoted to a discussion of this great industry. I think the thing that is bound to strike one most in listening to Prof. Gardiner's lecture is the importance of the discoreries made by means of scientific investigations with regard to the habits and movements and the growth of fish. One cannot help feeling that the time will not be very far off when we shall have something like a really exact knowledge of the development of fish. As he tells us, you have good seasons for fish and bad seasons for fish. The two industries with which I am particularly connected at the present moment, agriculture and fisheries, seem to me to have a good deal in common. Both are dependent to a great extent upon the weather; both are dependent upon the conditions of any particular year, and as our knowledge of these things increases, so we shall begin to estimate with greater certainty the catch of fish that is going to be brought to these shores every day, and so we may hope to secure the permanence of the supply of fish for the markets, not only of this country, but the markets of the world. At the end of his remarks Prof. Gardiner mentioned the scientific investigations which have been carried on for a number of years by - to give it its right name-the International Council for the Exploration of the Sea. It is one of those international bodies which by its very nature and composition is apt to move rather slowly. It has representatives on it of almost all the Western Powers of Europe and the United States, and unfortunately, of course, the war has upset it as it has upset many other thing. I am glad, however, that although its operations are for this year seriously curtailed, it is only in a state of suspended animation, and we hope that with the advent of peace the Council will be able to resume its work with all its old vigour. I am convinced that the work which is being done by that body, the systematic exploration of all the problems of the sea, is the one thing that is going to bring us conclusive results on all these problems. The share that this country has taken in the work has been, at any rate on one side of it, satisfactory from our point of view. I think we can say that the British representatives have supplied a great deal of initiative, have undoubtedly done a great deal to co-ordinate the work, and have contributed the greater part of the statistical work which is so necessary on a subject of this kind; but of the other side of the work, the work which is a necessary corollary to that, namely the work of the sea investigations, I am sorry to say we have not perhaps borne a pre-eminently great share. I am afraid England at the present time is the only country which has not got a properly equipped fishery research vessel of her own, and I can only say I sincerely hope I shall continue in my present office long enough to see that evil remedied. I do not think any reference to the subject of the fishing industry would be complete without some mention of what is being done at the present time by the fishermen of this country. Of all those who are assisting the country at the present moment with their services there is no class whose doings fall so heavily under the ban of the censor as does the work which is being done by our fishermen at the present time. But I am perfectly convinced, when the time comes, when the seal of secrecy can be removed, and when the doings of our fishermen, assisting the Admiralty as they have done, volunteering in large numbers for the navy, supplying a great part of our mercantile marine, as they habitually do, when the whole of their works have been brought to the notice of this country, I an sure we shall realize that the fishing industry is second to none, first of all as an industry of economic importance, and secondly as breeding the most virile class of men this island can produce.

Sir Norval W. Helme: I have the honour to-night of seconding the vote of 
thanks that has been proposed by Lord Lucas. I do so with particular pleasure because I had the opportunity of serving with Prof. Gardiner some years ago on a Parliamentary Committee, when the question was referred as to whether the Government should continue its grant to the International Committee for the purpose of the scientific study of the life and conditions of the fisheries in the North Sea. The matter of food supply has engaged the attention of the people of this country for many years, because of the great increase of population we have had during the last century, and the needs to provide good and wholesome food for the people. During the last few years arrangements have been made by which local authorities around the coast might become responsible for the oversight of the fisheries along the shores of the country, and so it is that the two departments, national and local, stand out as part of a great interest for supplying the people of this country with the food that is so good, namely, those that fish in the wider seas, and those that fish in the territorial waters around our shores. There is, unfortunately, a great feeling of competition between the inshore fishermen and those who trawl in the larger ships, and at the present moment we find that whilst the one is extending and has already attained the enormous proportions that have been mentioned by the lecturer, the supplies got by the inshore fishermen have been gradually becoming less, and so it is that the Government appointed a Departmental Committee which met last year to consider what could be done for the benefit of the inshore fisheries. Looking at the question as a whole, I would point out, in the presence of Lord Lucas, that the report of the committee on which Prof. Gardiner served has been upon the shelves of the department for some seven years since that report was made, and comparatively nothing has been done. At the present time, when we are having an income tax of $2 s .6 d$. in the pound, and other terrible consequences of the war upon us, we can quite excuse a Government Department for not hurrying up some recommendations which involve expenditure of money, but we do require legislation, and, as the report suggested, there should be concentration at headquarters in the oversight of the management of our fisheries. Owing to the arrangement by which the affairs of England, Scotland, and Ireland are administered separately financially, the different countries spend different amounts of money obtained from different sources in support of their fishing industries, and what was recommended by that committee I think is worthy of special consideration at the present time, because if we had a united council, I think we should have greater unity in carrying out the great measures that might affect the fishing around our shores. There is no doubt if the scientific study is supported by the Government we shall have greater advantages in the future. Locally, in the north of England, if I may venture to give one illustration, the Lancashire and Western Sea Fisheries Committee have inrested money and provided a vessel of their own, to do what the Government has hitherto not attempted, to undertake the scientific study of waters around our shores, and it is by this work Prof. Herdman has given great help in directing the scientific efforts of the local sea fisheries committee, and great good has been done. In addition to the fishes of which Prof. Gardiner has spoken to-night, there is the great shellfish industry, and that requires careful support, and it was a matter of interest to have put before us when that committee took evidence (Prof. Gardiner will remember the evidence). It was shown that by the investment of a little money and effort on the part of those connected with the mussel fishery it produced enormous advantage, because owing to the fact that in the seaweed attached to the rocks on the seashore there are thousands of small mussels which only require transplanting and having more room given them in which they could grow, the increase in the size of the fish was enormous, so that a tremendous addition was made to the 
available food supply. I have only ventured to allude to these points, but of course I recognize it is an opportunity we do not always get to bring a little pressure to bear upon the head of a Government Department when we are meeting outside the Houses of Parliament-in the presence of the Geographical Society-and I do think we may, at any rate, press the Government to consider further some suggestions that have been made. Prof. Gardiner alluded to the fact that out of 500 millions of plaice that are gathered only 200 millions are available for food, 300 millions are killed and wasted because of the method that is adopted in the taking of the fish. We must have a law passed to prevent the taking of immature fish. If we could have that, I think it would tend to allow the increase of the fish to be continued at an increased ratio, because the destruction of so many of these young fish naturally affects the home supply available.

Prof. E. W. MACBRIDE: I have much pleasure in supporting the motion of thanks to the lecturer for his most interesting lecture. It was also a very great pleasure to hear Lord Lucas, who discoursed so eloquently upon the subject of the necessity of scientific investigations in matters relating to fish, and I think, as a practical zoologist, the question immediately arises, the condition of the fisheries being what the lecturer Prof. Stanley Gardiner has indicated, how can they be helped by scientific people? It seems to me the scientific zoologists might try to do three things : First, they might try to help the fishermen to find the fish, and I suppose that is one of the main objects of the investigations which have been so heartily commended by Lord Lucas, because we know that fish in different years pursue different courses. We know that sometimes when the mackerel come up the Channel they strike the coast in one place and sometimes in another, and the fishermen sometimes suffer a complete loss through ignorance of where to look for the fish. If we were able to tell them where they would be likely to get the fish such loss would be avoided. Secondly, they might endeavour to prevent the depletion of fisheries by over-fishing. I was shocked to hear the rate at which the plaice fishery was being worked. I had not got any idea that we were approaching so near the limits of our supply. The fishery for halibut on the other side of the Atlantic -on the western side-was pursued by large fishing boats on the coasts of the eastern states of the Union. They fished out the halibut banks so completely that it no longer paid them to work there. They then paid their attentions to the Pacific coast, and actually invaded the inlets of British Columbia, and shipped the fish a 3000-miles journey by land and sold them in the New England States. The fishery, therefore, off the eastern coasts of the United States was almost depleted, and what has happened there might happen here. Thirdly, they might examine whether, in any way, it would be possible to increase the stock of fish artificially. I think what Prof. Gardiner has shown us to-night will convince most people of the utter futility of attempting to increase the stock of fish by the artificial hatching of eggs, and then letting the fish-fry escape into the sea. When one thinks of all the millions of fish eggs found over the enormous area occupied by the fisheries, one would realize the futility of trying to increase the stock of fish by throwing two or three million eggs a year from some local spot into the sea. I feel greatly encouraged by the kind and sympathetic way in which this motion for a vote of thanks has been proposed by the head of the Board of Agriculture and Fisheries.

Mr. H. G. MaURICE : I am not quite sure whether it is in order, under ordinary circumstances, for an administrative officer to speak in the presence of his President [Lord Lucas], but I have my President's kind permission. I am going first, if I may, to refer to those counsels of perfection which Sir Norval Helme has been giving us. He has suggested to us we should have a united authority for fisheries, and by a 
united authority I know he means an authority which is responsible for England, Scotland, and Ireland. Well, I admit that that is a counsel of perfection, but I would remind you of two things. The first is, that we have recently passed a Home Rule Bill, and the second, that Scotland is very tenacious of its own authority and rights -as also is the Lancashire and Western Sea Fisheries Committee-and I suggest that the first result that would ensue from the constitution of that united authority would be a number of broken beads. We have seen it discussed in various connections, and I am afraid the united authority is as far off as ever it was. There is no reason why we should have no vessel of our own; Sir Norval Helme has told you that we have done nothing. That is an over-statement of the case. The President of the Board has said that we have not got a ship of our own. In so saying he stated no more and no less than the precise truth. We are not the owners of a ship, but I look forward to the time when we are able to bring the necessary pressure to bear on the Treasury to enable us to get that ship. Meanwhile, we have been hiring ships and doing a very large amount of sea-research work, and, standing here to represent the administrative side of the Board of 'Fisheries, I cannot allow the challenge to pass or admit that we do not do a great deal. Sir Norval Helme referred also to the question of immature fish, and expressed the horror we all feel at the amount of waste which takes place. He said we must have legislation to stop it. One of the objects of our scientific investigations is to find out how you can achieve that. Up to the present nobody has been able, so far as I am aware, to devise a trawl net which will enable you to take the mature fish without destroying a large proportion of immature. I know a great many experts are in favour of legislation to regulate the size of the mesh, so that it will allow immature fish to slip through, but, speaking with all deference in the presence of experts, I believe I am right in saying, that the mesh which will let through, we will say, the immature plaice, or the bulk of the immature plaice, will also let go the mature sole, because the sole is rather remarkable -he can compress himself into a narrow space without inconvenience to himself, and he will escape though of marketable size, while the plaice you wish to liberate may even remain in the net. So much for those points. I wish now to refer to one point which Prof. McBride made. He referred to the futility of attempting to increase the stock of fish by hatchers, and releasing a quantity of fry in the very vast area of water with which we have to deal. I am not going to enter into a discussion of scientific problems, but there is one point which we have thought may be worth considering seriously, and that is the extraordinary growth of plaice transported from the nursery grounds to the Dogger Bank. If we could only devise some means by which the plaice which were transplanted could be protected internationally, that is to say, if we could prevent one group of fishing vessels coming in and (if I may use a colloquialism) scooping the lot while the others were waiting for them to grow, I do think an experiment of that kind would be worth trying. So far, however, we have not been able to see our way to arrange such an experiment on lines satisfactory to all nations concerned. There are experts here whom you will be wishing to hear who can speak to you about the scientific details, and I as an administrative officer am always very anxious to steer clear as far as I can of the controversial lines of fishery science, but 1 want to emphasize the three points Prof. McBride has already put before us. We want to find out, if we can, to what extent it is necessary to protect fisheries, and having discovered that much, how they can be protected. That is object number one. The next question is, whether we can see our way to foster the development of fisheries-that is, to increase the abundance and improve the quality of the fish. That is an extremely problematical question. The third is what I may describe as the motto of the International Council, the rational exploitation of the sea-that is to secure the greatest possible catch without 
detriment to the stock of fish on the grounds. All of those problems depend upon those physical geographical conditions which Prof. Gardiner has put before us this evening, and it is the study of that physical geography of the fisheries which is the groundwork, backed by statistics, of all our fishery investigations, and I think Prof. Gardiner was intentionally leading up throughout his lecture to the few words he said at the conclusion about the International Council for the Exploration of the Sea. The geography of the fisheries is a geography of physical conditions of environment, but there is also the topography to be taken into account. The physical conditions vary very largely with the topography, and the area we have to cover to get to the root of the matter is so wide that unless we can have the assistance of our fishing neighbours, we cannot possibly hope to cover it, to acquire that mass of information, and to sift that mass of information, which is necessary to lead us to true conclusions. I, personally, was extremely glad, and you appeared to appreciate the importance of the statement, when Lord Lucas said this evening that he looked forward to the time when under his Presidency we should be better equipped than we are at present for the purpose of these international investigations in which we have so important an interest.

Mr. F. Grant Ogilvie : One word I think is worth saying. I wish to offer congratulations upon a feature of this lecture that has not been referred to, but ought not to pass unnoticed. I thoroughly endorse all that has been said already as to the lecture itself; I wish, however, to draw attention to the audience. I think there is something absolutely novel and very satisfactory in the presentation of a lecture on this subject to such an audience. It is a well-known fact that in this country the national assistance to scientific investigation never gets very much in front of popular knowledge. Accordingly, until people at large get to know a little more about the sea, get to realize a little more fully that the sea is not merely a lucky bag - the prevailing notion is of this sort-and get to have some idea that the sea is worth investigating, we shall not have any real backing for the call for the support of scientific investigations. I hope there will be many opportunities for such popular illustrations of the leading lines of investigation as we have had to-night, and I am sure that an advance of the kind could not have had a better start than it has had this evening.

The President : Unless there is any other Fellow who particularly wishes to address the Meeting, I think the time has come when I ought to wind up the discussion by proposing the vote of thanks, in which I am sure we shall all cordially join, to Prof. Stanley Gardiner for the very instructive and interesting lecture he has given us. I am in the position of one of those who most needed instruction, for I knew nothing of fisheries except their products after the catch has come to dry land. I have looked with interest at the varied spoil of the sea ranged on the quays of Whitby, under the sheds by the Rialto in Venice, and, best of all, beside the long lanes of that wonderful place, the fish-market of Tokio. The display of fish to be seen there is, perhaps, the largest and the fish the strangest that one sees anywhere. Next to ourselves the Japanese are probably the greatest fishermen in the world, I have no doubt their practice as fishermen is one of the reasons of their naval efficiency. Of the close and delicate accuracy of Japanese representations of fishes every one familiar with their national art is well aware. What has struck me is the difference in the fishes of the different seas and oceans, how the fish-stalls emphasize the effect of environment on the development of fishes. I am sure this is a subject open to the investigations of many students-how all these fishes arrive at the weird forms in which we see them.

We have talked about the distribution of fishes ; here again I must confess that my knowledge of their distribution is confined to that which takes place after they 
are caught. But there are some picturesque incidents connected with it which have come to my knowledge in different ways. One I had from Mr. Spotswood Green, who has just retired from a high post connected with the Irish Fisheries. He told me that the Japanese war injured the fishermen on the west coast of Ireland because it reduced the demand at Petrograd, where the best lobsters were always sent. Again, in the north of Norway one may often get a good glass of port. This is due to the fact that the Norwegian boats which go down with cargoes of salt fish to Portugal before the Lenten fast, come back with port wine as ballast. Another incident of the same kind was told me by an eminent antiquary, who assured me that while digging up a Roman camp near Worcester, the shells of west coast oysters were found in the soldiers' quarters, but in the officers' quarters they were those of Colchester natives; an incidental proof of the excellence of the Roman roads in Britain.

We have not only to thank the lecturer to-night, but also to thank Lord Lucas, his fellow-officials, and the other speakers who have carried on a discussion which has been eminently practical, and may, I hope, have some permanent results in leading to these improvements in our provisions for fishermen and fisheries which have been foreshadowed. We offer our most hearty thanks to you, Prof. Gardiner, for the trouble you have taken in order to give us your lecture and to illustrate it so admirably.

\section{SUESS'S CLASSIFICATION OF EURASIAN MOUNTAINS.*}

\section{By Professor J. W. GREGORY, D.Sc., F.R.S.}

I. Current Classification of the Eurasian Mountain Systems. II. Prof. Suess's Classification. 1. The Primitive Nucleus. 2. The Altaid Zone. (a) The name Altaid; (b) The western Altaids; (c) The posthumous Altaids; (d) The eastern Altaids. 3. The Marginal Ares of Eurasia. III. Discussion of the Classificition. 1. The Value of the Foundation in Mountain Classification. 2. 'The Correlation of Europe and Asia. 3. The Relations of the Mountains of North-Eastern Siberia.

\section{Current Classification of the Eurasian Mountain Systems.}

THE traditional view of the arrangement of the mountains of Eurasia represents the Continent as traversed from the Pyrenees to Java in the south-east and to Bering Strait in the north-east by a connected series of mountain chains, which includes the Pyrenees, Alps, Carpathians, and Balkan Mountains in Europe, the Caucasus, the chief mountains of Persia and Afghanistan, the Himalaya and various adjacent chains, the western mountains of Burma, and the disrupted chain represented by the islands along the south-western coast of Sumatra. The main mountain line of this series enters Asia from Europe with a southerly trend. It almost at once turns northward; and it is significant that the Caspian depression occurs at the angle formed by this sudden change in course. The northerly trend of the Asiatic lines is occasionally interrupted; but in eastern Asia it is well marked by the convergence of the eastern chains

* Royal Geographical Society, March 4, 1915 